\title{
Seasonal dynamics of zebra mussel parasite populations
}

\author{
Laëtitia Minguez, Laure Giambérini* \\ Laboratoire des Interactions, Ecotoxicologie, Biodiversité, Ecosystèmes (LIEBE), CNRS UMR 7146, Université de Lorraine, \\ Campus Bridoux, Rue du Général Delestraint, 57070 Metz, France
}

\begin{abstract}
The seasonal dynamics of 8 parasite taxa in zebra mussels Dreissena polymorpha were studied in the Meuse River (NE France) over a $3 \mathrm{yr}$ period. In total, $69.5 \%$ of sampled organisms were infected. Among observed parasite species, Ophryoglena spp. and to a lesser extent Rickettsiales-like organisms (RLOs) displayed seasonal dynamics, with lower prevalence during warmer months negatively correlated with gonadal development in the host, water temperature and phytoplankton concentration. Furthermore, this study highlights a positive correlation between the prevalence rates of Ophryoglena spp. and RLOs. No temporal variations were observed for the ciliates Sphenophrya dreissenae and Conchophthirus acuminatus. Concerning trematode infection, no defined seasonal pattern was observed. Thus, for more reliability in future biomonitoring studies involving zebra mussels, it will be important to include the influence of parasites and their temporal dynamics.
\end{abstract}

KEY WORDS: Parasitism $\cdot$ Season $\cdot$ Dreissena polymorpha $\cdot$ Biomonitoring

Resale or republication not permitted without written consent of the publisher

\section{INTRODUCTION}

Numerous studies have reported the importance of parasites in structuring communities (Minchella \& Scott 1991). Indeed, parasites, as a major component of all ecosystems, can affect their hosts in different ways, for example by modifying host population dynamics (Møller 2005) or food-web dynamics (Marcogliese \& Cone 1997, Kuris et al. 2008). The effects of parasites include the use of the host's energetic reserves for the parasite's own development, an increased mortality, a disturbance of behaviour (locomotion, feeding, etc.) or the modification of life history traits (Mouritsen \& Jensen 1994, Marcogliese \& Cone 1997, Plaistow et al. 2001, Médoc et al. 2006). Despite their relative abundance in ecosystems, since every living organism can be the host to a parasite, the knowledge of factors involved in the emergence and spread of pathologies related to parasites and pathogens is still imperfect. The improvement of knowledge in this research area should begin with a better understanding of host-parasite interactions (Renault 1996). Moreover, these interactions are also of major concern in environmental risk assessment procedures since parasites can interact with pollution either as confounding factors if they are not taken into consideration in ecotoxicological studies (Kraak \& Davids 1990, Sures 2004, 2008, Minguez et al. 2009, Marcogliese \& Pietrock 2011), or as indicators of water quality (i.e. effect or accumulation indicators) (Sures et al. 1997, Pietrock \& Marcogliese 2003, Sures 2004, Minguez et al. 2011).

Among freshwater invertebrates commonly used in biomonitoring, zebra mussels Dreissena polymorpha are considered to be a reliable bioindicator species, because they are common in many shallow freshwater environments, easy to collect in large numbers, able to accumulate high concentrations of micropollutants and are sedentary. Thus, these bivalves can reflect site-specific pollution (Claudi \& Mackie 
1994). D. polymorpha is an invasive species that has successfully colonised a wide range of ecosystems throughout Europe and North America, where it has become common over wide areas (McMahon 1996). Like a very large number of organisms, zebra mussels have been documented to have a variety of parasites needing one or several hosts to complete their life cycles. Among these, we focused on parasites common in our study area: (1) commensal (Conchophthirus acuminatus) and parasitic ciliates (Ophryoglena spp. and Sphenophrya dreissenae), (2) intracellular bacteria (Rickettsiales-like organisms [RLOs]), and (3) 3 trematode species, Phyllodistomum folium, Bucephalus polymorphus and Echinoparyphium sp. (Molloy et al. 1997, 2001, 2005).

In the framework of environmental parasitology, a better understanding of interactions between parasite species and host is necessary. However, these interactions are poorly documented in the freshwater zebra mussel, in contrast with other invertebrate species presenting an economic interest. The present study aimed to acquire information on the temporal dynamics of Dreissena polymorpha parasite populations that could help to improve standardisation of ecotoxicological studies using this species as a test organism. We conducted seasonal parasite surveys over a period of $3 \mathrm{yr}$ in the Meuse River in northeastern France, and discuss herein in the relationships with mussel reproduction and environmental factors.

\section{MATERIALS AND METHODS}

\section{Sampling}

Between 30 and 200 zebra mussels were handpicked at between 80 and $120 \mathrm{~cm}$ depth from the rocky shores of the Meuse River at Commercy $\left(48^{\circ} 45^{\prime} 21.29^{\prime \prime} \mathrm{N}, 5^{\circ} 36^{\prime} 25.37^{\prime \prime} \mathrm{E}\right)$, a relatively unpolluted site, between January 2006 and October 2008 (for more details on site physico-chemical characteristics see Minguez et al. 2009). The samples were not taken at regular intervals but they followed the seasons. Only organisms with a shell length between 20 and $25 \mathrm{~mm}$ (i.e. adult mussels) were examined for the parasite survey. On each sampling date, the water temperature was measured directly in the field. The other parameters (chlorophyll a [chl a] and phaeopigment concentrations in water, and suspended matter) were obtained from the French Water Agency database (Agence de l'eau Rhin-Meuse, see www.eaurhin-meuse.fr).

\section{Parasite identification and counting}

Histological methods were used for the samples: fixing in Bouin's fixative, rinsing in water, dehydrating in a graded series of ethanol-toluene, embedding in paraffin, tissue sectioning (5 $\mu \mathrm{m}$ thickness), and staining with Gill II haematoxylin/eosin. A semiquantitative parasite inventory was made by observing 30 to 40 tissue sections per mussel, and parasites were identified following Molloy et al. (1997, 2001, 2005). The level of infection was assessed using standard epidemiological parameters (Bush et al. 1997): prevalence (percentage of mussels infected) and mean intensity (mean number of parasites per infected mussel) only for parasites that could be enumerated, i.e. individual cells of Ophryoglena spp., and cytoplasmic inclusion bodies of RLOs.

\section{Gonadal index determination}

To examine for a potential link between parasite infection and the host reproduction status, a mean gonadal index was assessed by microscopic observation of the slides (Tourari et al. 1988). Mussels were classified in 1 of 6 successive stages of gonad maturation, common or not to both sexes: an apparent sexual rest (Stage 0), gametogenesis initiation (Stage Ia), early gametogenesis (Stage Ib for males and Stage IaPrS for females), advanced gametogenesis (Stage II for males and Stage IaS for females), sexual maturity (Stage III for males and Stage IaPostS for females) and spawning (Stage E). An arbitrary score from 0 to 5 was attributed to each stage, and the following formula was used to calculate the gonadal index:

$$
\text { Gonadal index }=\left(\sum \mathrm{n}_{\mathrm{i}} \times \mathrm{s}_{\mathrm{i}}\right) / \mathrm{N}
$$

where $n_{i}$ is the number of individuals in each stage, $s_{i}$ the score of the stage and $\mathrm{N}$ is the total number of individuals.

\section{Statistical analysis}

All the statistical analyses were undertaken using $\mathrm{R}$ v.2.8.1. A $\chi^{2}$-test was used to evaluate differences in prevalence rates. Mean infection intensities were log transformed to the normality and the homogeneity of the data, and examined with a 1-way ANOVA. The Spearman rank correlation coefficient $\left(\mathrm{r}_{\mathrm{S}}\right)$ was used to evaluate the strength of the relationships between (1) prevalence rates of Ophryoglena spp. and RLOs, (2) infection intensities and prevalence 
rates, and (3) prevalence rates and gonadal index and environmental factors.

\section{RESULTS}

From 915 zebra mussels collected during the study period, $636(69.5 \%)$ presented with parasites, which belonged to 8 taxa (4 protozoans, 3 helminths and 1 bacterium) (Table 1). Among the ciliates, the commensal Conchophthirus acuminatus and the parasite Sphenophrya dreissenae did not show seasonal variations in occurrence (data not shown). In contrast, the infection by Ophryoglena spp. displayed seasonal dynamics in the Meuse River over the $3 \mathrm{yr}$ survey (Fig. 1), with lower prevalence during warmer months (i.e. spring and summer) and the highest reaching $97 \%$ during cooler months and negatively correlated with the water temperature $\left(\mathrm{r}_{\mathrm{S}}=-0.69\right.$, $p=0.01$ ). Furthermore, periods with higher prevalence (e.g. winter) were also significantly correlated to periods with mussels at the beginning of their reproduction cycle (low gonadal index) $\left(\mathrm{r}_{\mathrm{S}}=-0.78\right.$, $\mathrm{p}<0.01$ ) (Fig. 2). All environmental factors were negatively correlated with Ophryoglena spp. prevalence rate (suspended matter: $\mathrm{r}_{\mathrm{S}}=-0.61, \mathrm{p}<0.05$; chl $a$ and phaeopigments: $\left.r_{S}=-0.56, p=0.05\right)$. Moreover, mean infection intensity of Ophryoglena spp. followed the same pattern of prevalence (Fig. 1), with minimal values during spring and summer, signifi- cantly lower than in winter and autumn $(\mathrm{p}<0.01)$. Prevalence and infection intensity (log transformed) were correlated $\left(\mathrm{r}_{\mathrm{S}}=0.82, \mathrm{p}<0.001\right)$.

RLOs are intracellular bacteria infecting digestive gland cells. Prevalence and mean intensities of infection are given in Fig. 3. During winter and to a lesser extent in autumn, zebra mussels tended to be more frequently infected by RLOs, with a prevalence rate reaching $15 \%$. No correlations between prevalence and water temperature, infection intensity or gonadal index were observed. Infected zebra mussels displayed on average 2 RLO inclusions, without significant monthly variations. Despite the unclear seasonal pattern of RLO infection, the prevalence rates of RLOs and Ophryoglena spp. were positively correlated $\left(\mathrm{r}_{\mathrm{S}}=\right.$ $0.90, \mathrm{p}=0.01$ ). There were 5 times more zebra mussels infected by Ophryoglena spp. than by bacteria. Moreover, during this 3 yr survey at Commercy, cases of co-infections by Ophryoglena spp. and RLOs were observed in each sampling, representing a significant proportion of infected mussels $(10 \%)$.

Among other zebra mussel parasites, 3 genera of trematode species were found during the sampling period: (1) Phyllodistomum folium located in the gills, (2) Bucephalus polymorphus in the gonads, and (3) Echinoparyphium sp. (metacercarial stages), found in the connective tissue near the gonad and the digestive gland. The prevalence of these 3 species always remained low (i.e. $<15 \%$ ) and did not show clear seasonal patterns (Fig. 4).

Table 1. Dreissena polymorpha. Life cycles and infected organs for the 8 taxa observed infecting zebra mussels at Commercy (Meuse River) (modified after Martin \& Conn 1990, Conn \& Conn 1995, Molloy et al. 1997, Laruelle et al. 2002, Minguez et al. 2011)

\begin{tabular}{|c|c|c|c|}
\hline Species & No. of hosts & Host species & Target organs \\
\hline \multicolumn{4}{|l|}{ Bacteria } \\
\hline Rickettsiales-like organisms & $1^{\mathrm{a}}$ & Freshwater invertebrates & Digestive cells \\
\hline \multicolumn{4}{|l|}{ Ciliates } \\
\hline Conchophthirus acuminatus & 1 & D. polymorpha & Pallial cavity \\
\hline Sphenophrya dreissenae & 1 & D. polymorpha & Gills \\
\hline Ophryoglena spp. ${ }^{\mathrm{b}}$ & 1 & D. polymorpha & Digestive gland \\
\hline \multicolumn{4}{|l|}{ Trematodes } \\
\hline Echinoparyphium sp. & 3 & $\begin{array}{l}\text { 1st: freshwater snails (e.g. Lymnea stagnalis); } \\
\text { 2nd: D. polymorpha or tadpole or snail } \\
\text { (e.g. Radix auricularia); } \\
\text { 3rd: bird (e.g. greater scaup) }\end{array}$ & $\begin{array}{c}\text { Connective tissue } \\
\text { near gonads and } \\
\text { digestive gland }\end{array}$ \\
\hline Phyllodistomum folium & 2 & 1st: D. polymorpha; 2nd: fish (e.g. European bleak) & Gills \\
\hline Bucephalus polymorphus & 3 & $\begin{array}{l}\text { 1st: D. polymorpha; 2nd: fish (e.g. bream); } \\
\text { 3rd: carnivorous fish (e.g. European pike-perch) }\end{array}$ & Gonads \\
\hline
\end{tabular}




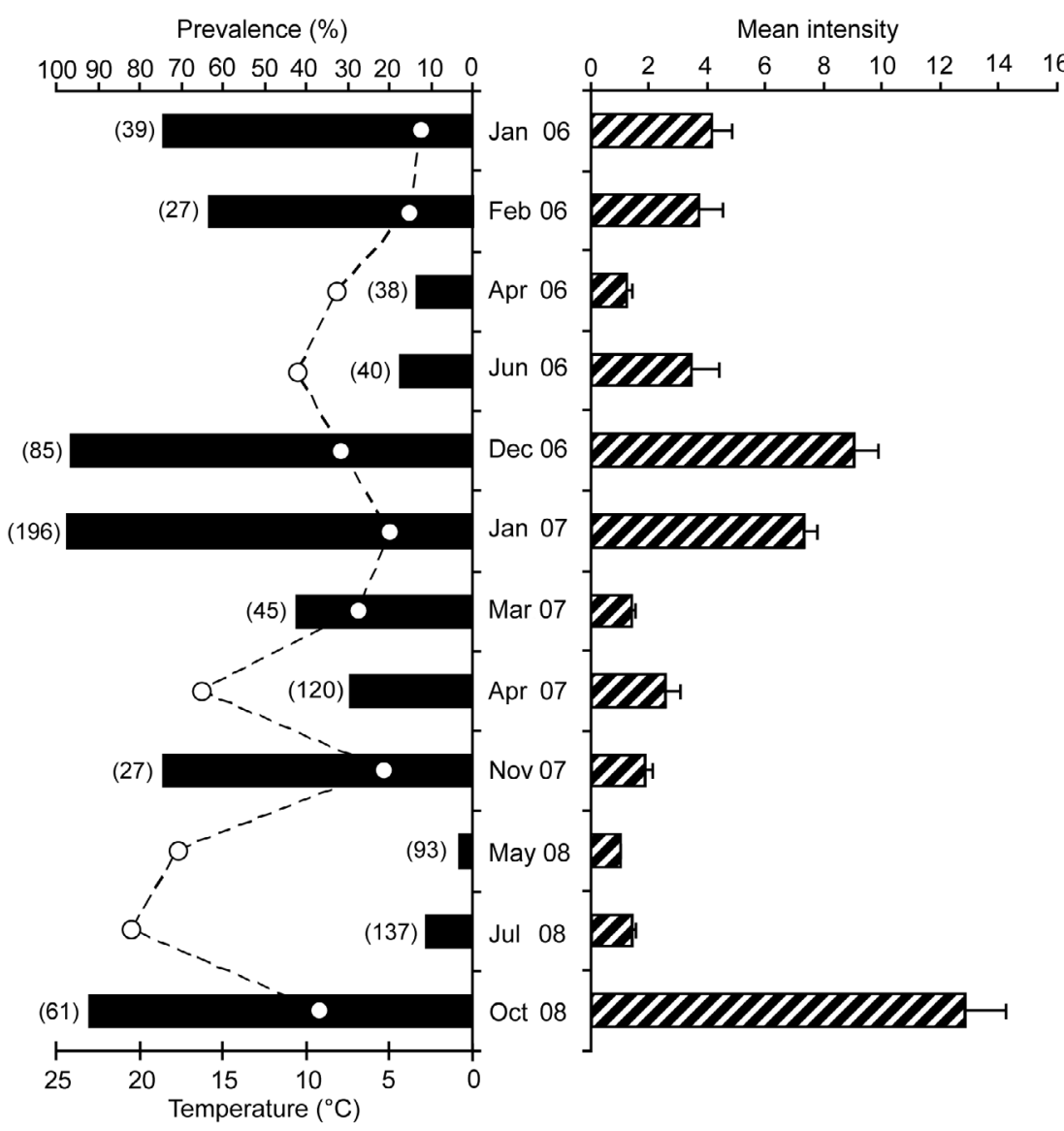

Fig. 1. Ophryoglena spp. infecting Dreissena polymorpha. Prevalence (\% of mussels infected) and mean intensity (no. of parasites per infected mussel) of Ophryoglena spp. observed in zebra mussels collected between January 2006 and October 2008. Sample sizes indicated in parentheses. Water temperature is also shown (dashed line). Error bars indicate SD

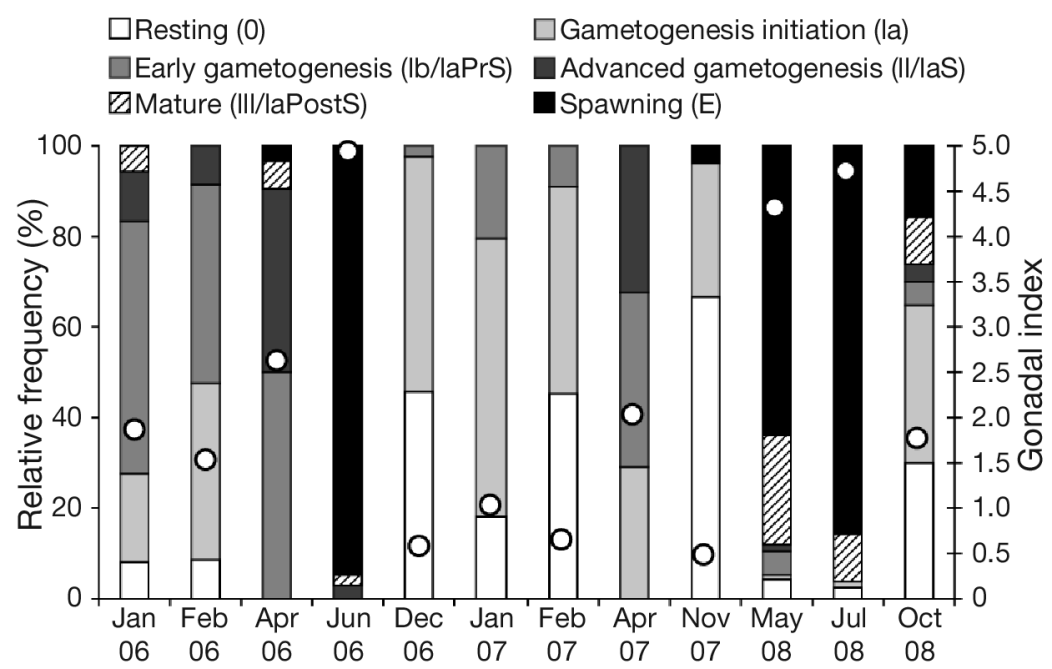

Fig. 2. Dreissena polymorpha. Relative frequencies of each gamete developmental stage observed in zebra mussels sampled between January 2006 and October 2008. Gonadal index values are also shown (white dot)

\section{DISCUSSION}

The dynamics of parasite populations observed in zebra mussels collected in the Meuse River at Commercy during 3 annual cycles are highly relevant in the environmental parasitology framework. Predominant parasites were ciliates belonging to the genus Ophryoglena. Two species, infecting the digestive gland lumina, were observed: the larger identified as O. hemophaga (Molloy et al. 2005) and a smaller undescribed species. The epidemiological parameters of these ciliates were characterised by strong seasonal variations, with the highest prevalence and intensities of infection during colder months. These seasonal patterns have been also observed in Belarus by Karatayev et al. (2003) but for shorter periods. The negative correlation between the prevalence rate of ciliates and temperature could be explained by a negative phototaxis during the protomont life stage observed in 2 Ophryoglena species $(O$. flava, $O$. hemophaga), emerging from the host (Cadetti et al. 2000, Molloy et al. 2005). As O. hemophaga is an obligate and host-specific parasite of zebra mussels, we could assume that when water temperature and sunlight increase in the warmer months, ciliates migrate deeper towards hosts fixed in the channel (lower temperature and light), but this hypothesis remains to be tested. In addition, Molloy et al. (2005) suggested that the negative phototaxis of $O$. hemophaga protomonts is likely to allow them to stay near their host rather than being carried away by water currents.

A second hypothesis related to host energetic reserves could be suggested to explain the observed correlation between Ophryoglena spp. prevalence and the temperature. The higher prevalence measured in winter could be linked to the high lipid and glycogen contents stored in the digestive gland, as reported in other surveys using zebra mussels (Sprung 1995, Guerlet et 


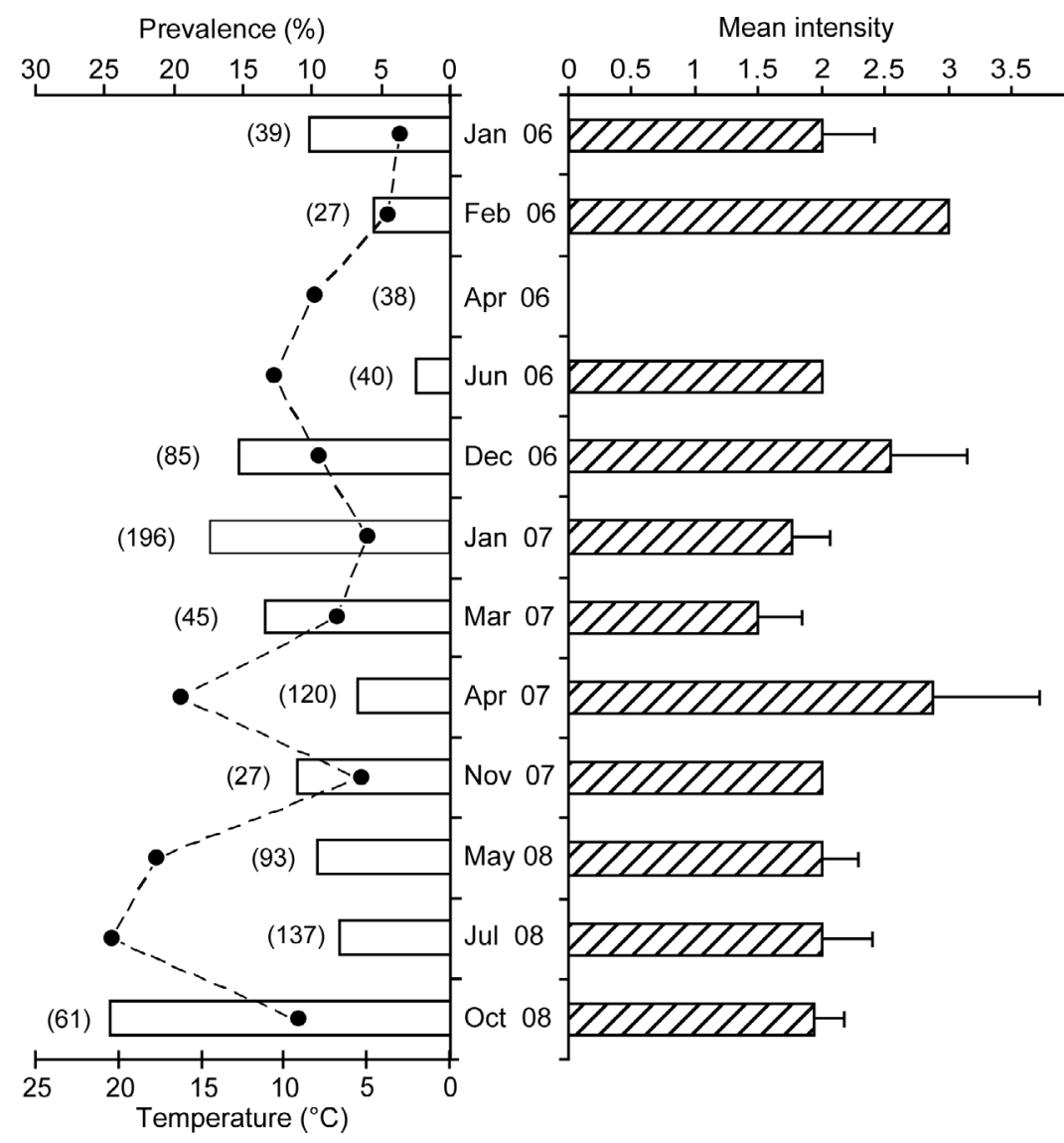

Fig. 3. Rickettsiales-like organisms (RLOs) infecting Dreissena polymorpha. Prevalence (\% of mussels infected) and mean intensity (no. of parasites per infected mussel) of RLOs observed in zebra mussels collected between January 2006 and October 2008. Sample sizes indicated in parentheses. Water temperature is also shown (dashed line). Error bars indicate SD

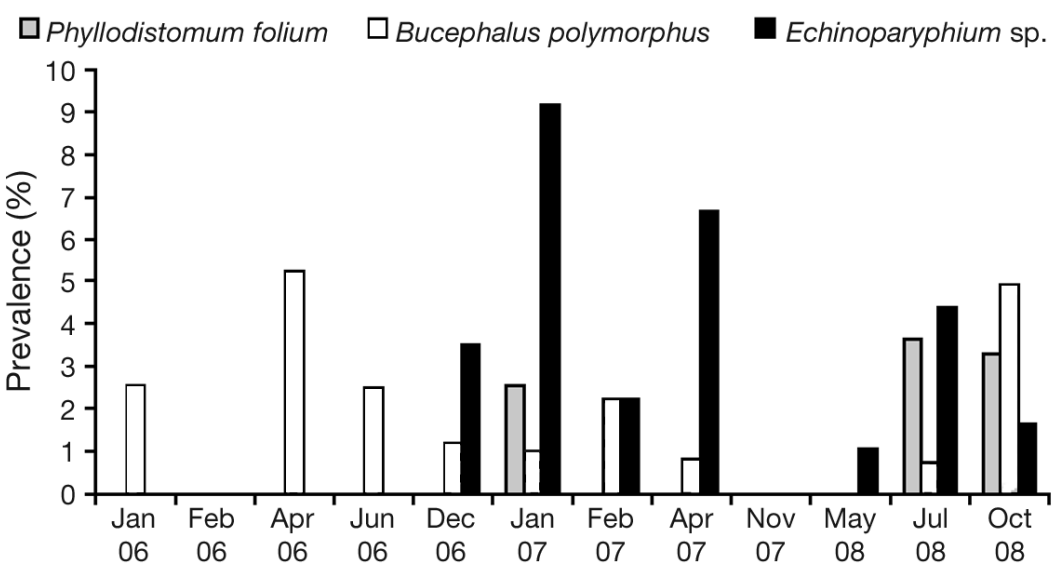

Fig. 4. Trematodes infecting Dreissena polymorpha. Prevalence (\% of mussels infected) of 3 trematode species observed in zebra mussels collected between January 2006 and October 2008: Phyllodistomum folium (gills), Bucephalus polymorphus (gonad) and Echinoparyphium sp. (connective tissue near gonad and digestive gland) al. 2007, Palais et al. 2011), which are potentially available for parasites. The digestive stock is then mobilised to the gonad during spring for gamete maturation, which could explain the reduction of Ophryoglena spp. prevalence rates. Our results suggest that both abiotic factors, such as water temperature or suspended matter, and related biotic factors such as chl $a$ and phaeopigment concentration in water, could play a role in the observed epidemiological parameter variations by directly affecting the parasite and/or indirectly affecting the parasite through host physiological changes that remain to be tested in further investigations. The relationship between prevalence and infection intensity suggests a link in the mechanism driving transmission among individuals at a population level and digestive gland physiology at an individual level, as Bates et al. (2010) proposed for another hostparasite system (i.e. sea stars Asterina miniata or Pisaster ochraceus and the ciliate Orchitophrya stellarum).

The RLO infection presented an unclear seasonal pattern, but was correlated with ciliate prevalence. In the present investigation, the study site (Meuse River at Commercy) is relatively unpolluted, but in other situations the relationship could also be influenced by the water quality at the study sites, since a positive correlation has been highlighted between RLO prevalence rate and the heavy metal levels in the sediment (Minguez et al. 2011). Both parasite species formed cases of co-infections representing a significant proportion of infected mussels $(10 \%)$, which Minguez et al. (2009) have shown to be marked confounding factors in ecotoxicological studies, since they can enhance the effect of pollution on biological responses of zebra mussels. Co-infection by Ophryoglena spp. and RLOs in particular can represent a substantial energy cost for the host, which is then more sensitive to pollution. 
In the present study, no clear seasonal dynamics were highlighted for the 3 trematode species, whereas the investigations reviewed by Molloy et al. (1997) reported maximal infection rates during warmer water temperature periods. Nonetheless, the prevalence rates found here remained usual (reviewed in Molloy et al. 1997).

\section{CONCLUSIONS}

The present study reports for the first time seasonal dynamics of zebra mussel parasite populations during a 3 yr annual cycle survey. Parasitological parameters of Ophryoglena spp., and to a lesser extent RLO infection, may be explained both by abiotic (e.g. water temperature, suspended matter) and biotic factors (e.g. host reproductive status, and chl $a$ and phaeopigment concentrations). This study also showed a relationship between (1) prevalence rate and mean intensity of ciliates and (2) prevalence rates of Ophryoglena spp. and RLOs, with a 5-fold factor in favour of Ophryoglena spp. Furthermore, no defined seasonal pattern was observed for trematode infection. As recommended by Minguez et al. (2011), temporal variations in infection parameters need to be considered before zebra mussel parasites can be used as bioindicators in water quality assessments. Moreover, we have provided essential data for improving the standardisation of sampling periods in ecotoxicological studies and reducing the potential confounding factor linked with infection. Several sampling periods are suggested: either spring or winter samplings in shallow areas. In spring, zebra mussels are less infected and at the beginning of gametogenesis, so they are less sensitive to environmental factors than during the spawning stage in summer. In contrast, in winter a very large number of organisms are infected, decreasing the inter-individual variability related to parasitism.

Acknowledgements. Many thanks to A. Meyer, A. Claudel and M. Sidot for their technical contribution. We thank S. Kruger for her careful correction of the English and the 2 anonymous reviewers for their helpful comments. This study was supported by an EC2CO Cytrix program of the CNRSINSU and the CPER Lorraine-ZAM (Contrat Projet Etat Région Lorraine, Zone Atelier Moselle).

\section{LITERATURE CITED}

Bates AE, Stickle WB, Harley CDG (2010) Impact of temperature on an emerging parasitic association between a sperm-feeding scuticociliate and Northeast Pacific sea stars. J Exp Mar Biol Ecol 384:44-50
Bush AO, Lafferty KD, Lotz JM, Shostak AW (1997) Parasitology meets ecology on its own terms: Margolis et al. revisited. J Parasitol 83:575-583

Cadetti L, Marroni F, Marangoni R, Kuhlmann HW, Gioffré D, Colombetti G (2000) Phototaxis in the ciliated protozoan Ophryoglena flava: dose-effect curves and action spectrum determination. J Photochem Photobiol B 57: $41-50$

Claudi R, Mackie GL (1994) Practical manual for zebra mussel monitoring and control. Lewis Publishers, Boca Raton, FL

Conn DB, Conn DA (1995) Experimental infestation of zebra mussels, Dreissena polymorpha (Mollusca: Bivalvia), by metacercariae of Echinoparyphium sp. (Platyhelminthes: Trematoda). J Parasitol 81:304-305

Guerlet E, Ledy K, Meyer A, Giambérini L (2007) Towards a validation of a cellular biomarker suite in native and transplanted zebra mussels: a 2-year integrative field study of seasonal and pollution-induced variations. Aquat Toxicol 81:377-388

Karatayev AY, Mastitsky SE, Burlakova LE, Molloy DP, Vezhnovets GG (2003) Seasonal dynamics of endosymbiotic ciliates and nematodes in Dreissena polymorpha. J Invertebr Pathol 83:73-82

Kraak MHS, Davids C (1990) The effect of the parasite Phyllodistomum macrocotyle (Trematoda) on heavy metal concentrations in the freshwater mussel Dreissena polymorpha. Neth J Zool 41:269-276

Kuris AM, Hechinger RF, Shaw JC, Whitney KL and others (2008) Ecosystem energetic implications of parasite and free-living biomass in three estuaries. Nature 454:515-518

Laruelle F, Molloy DP, Roitman VA (2002) Histological analysis of trematodes in Dreissena polymorpha: their location, pathogenicity, and distinguishing morphological characteristics. J Parasitol 88:856-863

Marcogliese DJ, Cone DK (1997) Food webs: a plea for parasites. Trends Ecol Evol 12:320-325

Marcogliese DJ, Pietrock M (2011) Combined effects of parasites and contaminants on animal health: parasites do matter. Trends Parasitol 27:123-130

> Martin TR, Conn DB (1990) The pathogenicity, localization and cyst structure of echinostomatid metacercariae (Trematoda) infecting the kidneys of the frogs Rana clamitans and Rana pipiens. J Parasitol 76:414-419

McMahon RF (1996) The physiological ecology of the zebra mussel, Dreissena polymorpha, in North America and Europe. Am Zool 36:339-363

Médoc V, Bollache L, Beisel JN (2006) Host manipulation of a freshwater crustacean (Gammarus roeseli) by an acanthocephalan parasite (Polymorphus minutus) in a biological invasion context. Int J Parasitol 36:1351-1358

Minchella D, Scott ME (1991) Parasitism: a cryptic determinant of animal community structure. Trends Ecol Evol 6: 250-254

Minguez L, Meyer A, Molloy DP, Giambérini L (2009) Interactions between parasitism and biological responses in zebra mussels (Dreissena polymorpha): importance in ecotoxicological studies. Environ Res 109:843-850

> Minguez L, Molloy DP, Guérold F, Giambérini L (2011) Zebra mussel (Dreissena polymorpha) parasites: potentially useful bioindicators of freshwater quality? Water Res 45:665-673

Møller AP (2005) Parasitism and the regulation of host populations. In: Thomas F, Renaud F, Guégan JF (eds) Parasitism \& ecosystems. Oxford University Press, New York, NY, p 43-53 
Molloy DP, Karatayev AY, Burlakova LE, Kurandina DP, Laruelle F (1997) Natural enemies of zebra mussels: predators, parasites, and ecological competitors. Rev Fish Sci 5:27-97

Molloy DP, Giambérini L, Morado JF, Fokin SI, Laruelle F (2001) Characterization of intracytoplasmic prokaryote infections in Dreissena sp. (Bivalvia: Dreissenidae). Dis Aquat Org 44:203-216

Molloy DP, Lynn DH, Giambérini L (2005) Ophryoglena hemophaga n. sp. (Ciliophora: Ophryoglenidae): a parasite of the digestive gland of zebra mussels Dreissena polymorpha. Dis Aquat Org 65:237-243

Mouritsen KN, Jensen KT (1994) The enigma of gigantism: effect of larval trematode on growth, fecundity, egestion and locomotion in Hydrobia ulvae (Pennant) (Gastropoda: Prosobranchia). J Exp Mar Biol Ecol 181:53-66

Palais F, Mouneyrac C, Dedourge-Geffard O, Giambérini L, Biagianti-Risbourg S, Geffard A (2011) One-year monitoring of reproductive and energy reserve cycles in transplanted zebra mussels (Dreissena polymorpha). Chemosphere 83:1062-1073

Pietrock M, Marcogliese DJ (2003) Free-living endohelminth stages: at the mercy of environmental conditions. Trends Parasitol 19:293-299

Editorial responsibility: Peter Beninger, Nantes, France
Plaistow SJ, Troussard JP, Cézilly F (2001) The effect of the acanthocephalan parasite Pomphorhynchus laevis on the lipid and glycogen content of its intermediate host Gammarus pulex. Int J Parasitol 31:346-351

Renault T (1996) Appearance and spread of diseases among bivalve molluscs in the northern hemisphere in relation to international trade. Rev Sci Tech 15:551-561

Sprung M (1995) Physiological energetics of the zebra mussel Dreissena polymorpha in lakes. I. Growth and reproductive effort. Hydrobiologia 304:117-132

Sures B (2004) Environmental parasitology: relevancy of parasites in monitoring environmental pollution. Trends Parasitol 20:170-177

Sures B (2008) Host-parasite interactions in polluted environments. J Fish Biol 73:2133-2142

Sures B, Taraschewski H, Rydlo M (1997) Intestinal fish parasites as heavy metal bioindicators: a comparison between Acanthocephalus lucii (Palaeacanthocephala) and the zebra mussel, Dreissena polymorpha. Bull Environ Contam Toxicol 59:14-21

Tourari AL, Crochard C, Pihan JC (1988) Action de la température sur le cycle de reproduction de Dreissena polymorpha (Pallas). Etude in situ et en laboratoire. Haliotis 18:85-98

Submitted: November 7, 2011; Accepted: February 15, 2012 Proofs received from author(s): April 26, 2012 